\title{
English, Modernity and the Decay of Local Language
}

\author{
Asna Usman Dilo, Sri Dewi Jayanti Biahimo \\ IAIN Sultan Amai Gorontalo, Jl. Gelatik No. 1, Kota Gorontalo, Gorontalo, Indonesia \\ Corresponding e-mail: asnadilo77@gmail.com
}

\begin{abstract}
This study aims at describing the correlation between English usage in daily interaction of young generation in Gorontalo and the decay of local language. It is a qualitative study where the data are taken from observation, interview, and documentation. The respondents in this study are young people of Gorontalo. It reveals that youth perceive using English and other dialects, such as, "Betawinese (native of Jakarta) and Manadonese (native of Manado, North Sulawesi)" dialect in their daily interaction as part of modern lifestyle. Whereas local language usage is seen as something traditional and only is used by older generations. This study also reveals that media and parents as the two key actors in the decay of local languages. At home communication between parents and children, and even parents to parents rarely use local language anymore. In addition, mass media, such as radio, Television, and local newspaper are no longer use local language. Out of many radio programs in Gorontalo, for instance, only two programs that use Gorontalonese language. Therefore, this study recommends that parents and mass media increase their usage of local languages in Gorontalo in order to slow down the decay of local languages in Gorontalo.
\end{abstract}

Keywords: modernity, local language, language decay

\section{INTRODUCTION}

Language like other being is prone to change, decay and even death. However, as an identity of certain ethnic and even a country, various efforts have been made to preserve language, especially local languages. Indonesia, as the second most diverse languages on earth (Harjanti, 26 ${ }^{\text {th }}$ August 2016,) who have 742 languages spoken all over nation is prone to face language decay and language death.

Language decay and language death are serious threats for local languages in Indonesia because there are hundreds of languages that are spoken by only less than a million number of speakers. Such as in Papua who has almost 300 languages, the population is less than two million. To add to this vulnerability, out of hundreds of languages in Indonesia, there are only thirteen languages spoken by more than a million speakers.

Local languages in Indonesia are not only decaying and dying due to the mentioned reasons above. Several other problems such as, languages that are only spoken by the senior generations is also a serious threat to the existence of these languages. The generation gap in language could cause the language to disappear. Other threats of local languages also come from mass media and other more superior languages. Thus, efforts to preserve local languages become more necessary.

Gorontalo is a province with a majority of Moslems population. The population of this province is 1,133,237 people (BPS, 2015) and at least four local languages are in danger of losing its local languages. These four languages spoken by people in Gorontalo are Gorontalo language, Suwawa or Bonda Language, Bulango Language, and Atinggola Language. In addition, people in Gorontalo also speak daily dialect that is close to daily dialect of people in North Sulawesi.

The dominant local language is Gorontalo language, which is spoken by the majority of people in Gorontalo. While Suwawa language is spoken by people in Suwawa sub-district and its surrounding sub-districts with speakers of roughly about 45.000 people. The third language spoken in Gorontalo is the Atinggola language. This language is spoken by the people in the North Gorontalo Regency, especially in Atinggola sub-district. The population of this sub-district is 10,706 (BPS, 2017). The last language and the almost extinct language in Gorontalo is the Bulango Language which supposed to be spoken by people in Tapa sub-district and its surrounding sub-districts in Bone Bolango regency. Sadly, the head of the Regency, Hamim Pou, 
revealed that currently there is only one family who still speaks this language (Azhar, October 2016).

On the other hand, modernity refers to a state of mind as well as social and economic condition (Gaddol, Leith, \& Swan, 1996). In this study, modernity refers to state of mind and social condition where people tend to feel free from traditional norms and culture. In the same tone, Taylor (in Elias, 2008) offered similar definition of modernization as a set of changes in institutions and practices and that those who fail to adapt to these changes would be left behind and eventually would be forced to undergo changes.

Thus, it becomes more interesting to see the state of the local languages in this area. And with the current trend of social media and globalization, where people tend to use English in their daily interaction, does it have effect on the decay of the local language. More specifically, on how the youth perceive their local language?

Through these questions, it is expected that the state of local languages in Gorontalo will be known as well as how the youth perceive the local language. Further, the efforts to at least slow down the decay and death of local languages in Gorontalo can be recommended.

\section{METHODS}

This study is a qualitative method to comprehensively study the phenomena of local languages in Gorontalo. The data are collected by unstructured interview with several local youths. The data are analyzed using data display, data reduction, and conclusion drawing (Sanafiah, 2015). The youths participated in this study are those aged 17-24 Years old and their participation in this study is voluntary. The study is conducted from June to September 2017. Participants in this study are youth who speaks at least one local language in Gorontalo.

\section{RESULTS AND DISCUSSION}

This study has revealed several findings related to how the youth view the English language as something modern and how their view on local language. Another interesting finding in this study is how at home interaction influences their mastery of local language.

\subsection{Using English and other dominant languages Seen as Modern}

The respondents have said that posting something in English on their social media page such as, Facebook made them feel prouder. Some even admit that they go to the extent of asking their friends who know English better about things that they want to say in English before pasting it as their status on their social media page. Even, some are desperate enough to use Google Translate application to translate what they want to say on their social media page.

There are also some who admitted that they prefer English songs to Indonesian songs, not to mention the songs in local languages. Thus, they frequented the radio stations who play English songs and often listen to radio announcers who mixed languages during their on-air time.

It was noted that regardless to various mistakes in the usage of English in social media statuses people keep posting them. Our respondents said the reason why they post things in English was that when they consider posting things in English as 'cool and sophisticated'.

In addition to English, they usually post and make comments on their social media page by using either proper Bahasa, Betawinese language, or Manadonese dialect. All respondents admitted that they almost never post things on their social media page in their mother tongue language.

This study indicated that the young people age 17-24 in Gorontalo prefer to talk and use English or other dominant languages than their own local languages. This could lead to a serious threat to the existence of local languages in Gorontalo. The extinction time of local language may be closing in as there would be a gap of generation that no longer speak the languages. This should become a concern for people in Gorontalo as the owners of the language as well as government to start thinking about ways to support the preservation of language.

This finding is consistent with what has been predicted by Taylor (as cited in Elias, 2008) that local languages in Gorontalo are undergoing some changes of how they are practiced. And as we fail to adjust the usage of these languages into the changes happen in our society. The languages have started to extinct at least as active communication language among the youths. 


\subsection{Parents-Children's Interaction}

Respondents of this study have mentioned that their interaction with their parents was no longer conducted in local languages. The mother tongues were only spoken on the occasion of big traditional events, such as marriage ceremony, or when there are generations older than their parents present. Some even mentioned that their parents would speak to them in their mother tongue when the parents were angry with them.

In addition, the mother tongue would also be used to discuss private matters in the presence of people from different language background. These have made the young generations in Gorontalo to become passive speakers of their own native languages. Or even become alien to use their own native languages.

\subsection{Media and Dominant Languages as Threats to local language}

The native languages in Gorontalo are also facing threats from the media; how mainstream media such as, television and radio, as well as digital mass media use either English, proper Bahasa, or dominant dialect such as, Betawi and Manado dialects in their programs also have added to the decay of local languages in Gorontalo.

As their parents no longer speak to them in their native tongue, their fellow youth also do not speak using native languages, the media also bombarded them with other languages that made the local languages become alien to its owners.

For instance, out of two local television stations, we observed at least only two programs that used local languages. And as these two programs mainly highlighted the life of rural people, these programs do not appear to have attracted the interest of the local youths. Our respondents said that they rarely watch the local television channels. So, they do not consider the programs as helpful in increasing their knowledge of their native tongue.

Further, there are at least ten radio stations in Gorontalo, out of these stations there are three stations who have program broadcasted in the dominant local language, the Gorontalo language. While other languages, Suwawa, Atinggola, and Bulango have no place in these media. Sadly, our respondents admitted that these programs have no appeal to them because either the program segment is not for youth or that they just do not listen to such program because they consider the program or even the radio stations that broadcasted the program not to their taste as they mainly play Dangdut songs or programs that they consider as traditional.

To add to this, the radio programs and stations that the youth mostly listened to are stations or programs that only played songs either in Bahasa or in English even Korean songs. The radio announcers also speak in Betawinese or what they called as Jakarta dialect. Thus, these youths have less and less contact with their native languages.

Interestingly, there is also a phenomenon that we observed, where youths that went abroad or outside of the regions, often come back and mastered the language while there were abroad. We suspected that this was due to the language as an identity. When they are abroad or not in their hometown, these youths tend to associate with people from their hometown and their identity as the people of certain region becomes more pronounced and in their interaction, they tend to use their mother tongue to differentiate with the language spoken around them or to show their identity.

\section{CONCLUSIONS}

This study has found that local languages in Gorontalo are in the process of extinction and that youths have some role in this such as:

1. They prefer to use English or other dominant languages in their interaction as they would like to be considered as modern people

2. Communication at home from parents to children is no longer conducted in their native languages, hence, there is a generation gap of native language users

3. Media and dominant languages also played the role in the decay of these local languages.

Therefore, we recommended that the government, speakers of the language and other stakeholders to start being aware of this trend and do some actions to at least slow down the language death and decay process by:

1. Parents to start communicate with their children using their mother tongue

2. Government to start to encourage the staffs to use local language. If we can have English day, why not have Gorontalo day or Suwawa day. Where people speak the language for at least several hours a day. 
3. For the language institutions and university to start to have real contribution to preserving these languages, especially languages that are on the brink of extinction, such as Bulango language. For instance, by creating a pictorial dictionary in these languages, so it appeals to children and youth. Or design some events or activity days where people can socialize using the mother tongues.

\section{ACKNOWLEDGEMENTS}

The authors wish to thank IAIN Sultan Amai

Gorontalo

\section{REFERENCES}

Azhar, A. Rosyid. (2016). Is There Any Bulango Language Speaker Left in Gorontalo/ Masih Adakah Penutur Bahasa Bulango di Gorontalo?. Kompas. Retrieved from: http:www.kompas.com

BPS. (2015). Gorontalo Province in Numbers/ Provinsi Gorontalo Dalam Angka. Badan Pusat Statistik. Gorontalo

BPS. (2015). Gorontalo Regency in Numbers/ Kabupaten Gorontalo Dalam Angka. Badan Pusat Statistik. Gorontalo

BPS. (2017). Atinggola Sub-district in Numbers/ Kecamatan Atinggola Dalam Angka. Badan Pusat Statistik. Gorontalo

Graddol, David., at.al. (1996). English: History, Diversity, and Change. Psychology Press, 79-80.

Harjanti, Annisa. (August 2016). Hundreds of Local Language in Indonesia are in Danger of Extinction/ Ratusan Ragam Bahasa di Indonesia Hadapi Ancaman Kepunahan, National Geographic. Retrieved from: http:www.nationalgeographic.co.id

Elias, Vivan (2008). The Implications of Modernity for Language Retention and Related Identity Issues: Applying the Thought of Charles Taylor, International Congress on Arctic Social Sciences (ICASS VI), Nuuk, Greenland, 22-26 August 2008.

Sanafiah, Faisal. (2005). Social Research Format/Formatformat Penelitian Sosial. Raja Grafindo Persada. Jakarta 